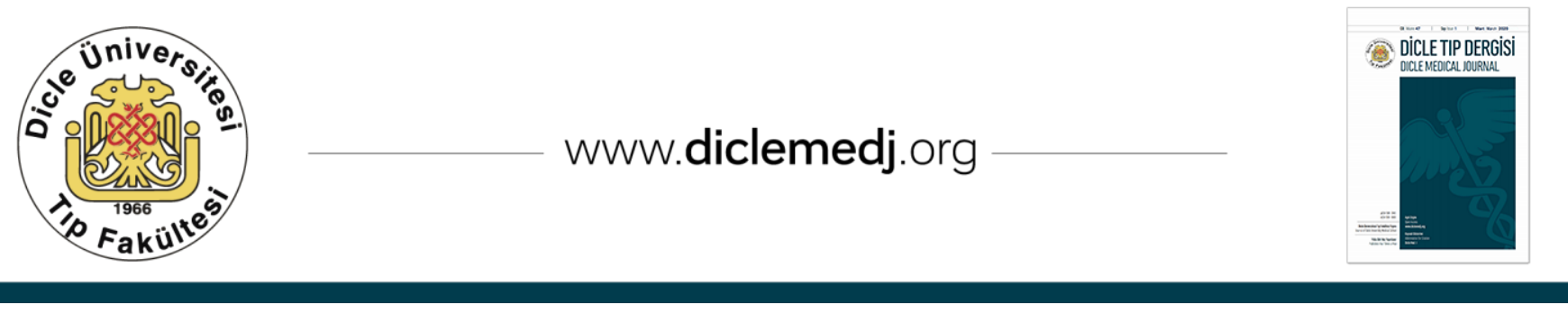

Original Article / Özgün Araştırma

\title{
The Concomitant Use Of Proton Pump Inhibitors And Pazopanib In Patients With Soft-Tissue Sarcoma: Is It Really To Be Avoided?
}

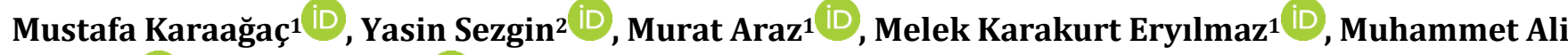 \\ Kaplan² $^{\text {iD }}$, Mehmet Artaç1 ${ }^{\text {iD }}$
}

1 Necmettin Erbakan University, Meram Medical Faculty, Department of Medical Oncology, Konya, Turkey 2 Dicle University, Medical Faculty, Department of Medical Oncology, Diyarbakir, Turkey

Received: 11.12.2019; Revised: 21.01.2020; Accepted: 22.01.2020

\begin{abstract}
Objectives: Pazopanib is an orally administered drug and has approval for the treatment of advanced Soft Tissue Sarcomas (aSTS). The absorption of pazopanib is $\mathrm{pH}$-dependent. Acid-Reducing drugs such as proton pump inhibitors (PPI) may reduce the bioavailability of pazopanib. The primary purpose of this study was to assess whether the use of concomitant PPI and pazopanib had negative effects on survival outcomes.

Methods: In this retrospective cross-sectional study, age $\geq 18$ years, having histologically proven STS, receiving pazopanib at least one day, and availability of information about the use of PPI during pazopanib treatment were the inclusion criteria. Patients with adipocytic sarcoma were excluded.
\end{abstract}

Results: A total of 46 eligible patients were assessed in this study. Thirty-one patients used concomitant PPI and pazopanib, 17 of them frequently used PPI, and the others occasionally. Fifteen patients never used concomitant PPI and pazopanib. The median progression-free survival (PFS) was 2.76 months, and the median overall survival (OS) was 7.39 months for patients who never used concomitant PPI and pazopanib. Also, the median PFS was 5.22 months, and the median OS was 14.52 months for patients who used concomitant PPI and pazopanib. In univariate analysis; using concomitant PPI $(\mathrm{p}=0.049)$ and primarily uterine located tumors $(\mathrm{p}=0.038)$ were significant parameters for PFS. In multivariate logistic regression analysis; both of using concomitant PPI (Wald=6.02; $\mathrm{p}=0.014$ ) and primarily uterine located tumors (Wald=5.69; $\mathrm{p}=0.017$ ) retained their association with longer PFS. No parameter was significant for OS.

Conclusions: We showed that the use of concomitant PPI and pazopanib was associated with improved PFS. These results may help guide clinicians and researchers for allowing patients co-administrating PPI and pazopanib, especially when treating or investigating patients with dyspeptic symptoms.

Keywords: pazopanib, proton pump inhibitor, concomitant, survival, sarcoma 


\section{Yumuşak Doku Sarkomlu Hastalarda Proton Pompası İnhibitörlerinin Ve Pazopanibin Eşzamanlı Kullanılması: Gerçekten Kaçınılması Gereken Bir Durum Mudur?}

Öz

Giriş: Yumuşak doku doku sarkomları oldukça nadir görülen ve heterojen bir kanser türüdür. Oral yoldan kullanılan bir ilaç olan pazopanib, ileri evre yumuşak doku sarkomlarının (aSTS) tedavisi için onay almıştır. Pazopanibin emilimi pH bağımlıdır. Proton pompası inhibitörleri (PPI) gibi mide asit düzeyini baskılayan ilaçların, pazopanibin biyoyararlanımını azaltabileceği yönünde farmakokinetik veriler bildirilmektedir. Bu çalışmanın birincil amacı PPI ve pazopanibin eşzamanlı kullanımının gerçek yaşamda sağkalım sonuçları üzerinde olumsuz etkisinin olup olmadığını değerlendirmektir.

Yöntemler: Bu bir retrospektif, kesitsel, kohort çalışmasıdır. 18 yaşın üzerinde olan, histolojik olarak kanıtlanmış aSTS' ye sahip, bir gün dahi olsa pazopanib kullanan ve pazopanib tedavisi sırasında eşzamanlı PPI kullanıp kullanmadığı hakkındaki bilgilerin belirlenebildiği hastalar çalışmaya dahil edildi. Adipositik sarkomu olan tüm hastalar çalışma dışı bırakıldı.

Bulgular: Bu çalışmada toplam 46 hasta değerlendirildi. Otuz bir hasta eşzamanlı PPI ve pazopanib kullandı, bunların 17 tanesi pazopanib ile birlikte hemen hergün PPI kullandı ve kalan 14' ü ise pazopanib ile birlikte PPI' ı bazen kullandı. On beş hasta ise hiçbir zaman PPI ve pazopanibi eşzamanlı kullanmadı. Hiç bir zaman eşzamanlı PPI ve pazopanib kullanmayan hastalarda ortanca progresyonsuz sağkalım (PFS) 2.76 ay ve ortanca genel sağkalım (OS) ise 7.39 ay olarak hesaplandı. Eş zamanlı PPI ve pazopanib kullanan hastalarda ise ortanca PFS ve ortanca OS değerleri sırasıyla 5.22 ve 14.52 ay olarak bulundu. Tek değişkenli analizde; eşzamanlı PPI ve pazopanib kullanımı $(p=0.049)$ ve primer uterin yerleşimli tümör varlığı $(\mathrm{p}=0.038)$ uzamış PFS için istatistiksel olarak anlamlı parametreler olarak saptandı. Çok değişkenli lojistik regresyon analizinde ise; hem eşzamanlı PPI ve pazopanib kullanımı (Wald =6.02; $\mathrm{p}=0.014$ ), hem de primer uterin yerleşimli tümör varlı̆̆ (Wald = 5.69; $p=0.017$ ) uzamış PFS ile olan istatistiksel anlamlı ilişkilerini korudu. Uzamış OS açısından ise hiçbir parametre anlamlı bulunmadı.

Sonuç - Yorum: Biz bu çalışmada, gerçek yaşamda eşzamanlı PPI ve pazopanib kullanımının PFS' de azalmaya yol açmadığını, hatta uzamış PFS ile ilişkili olduğunu gösterdik. Bu sonuçlar, özellikle dispeptik semptomları olan hastaları tedavi ederken veya araştırırken, sanılanın aksine PPI ve pazopanib'in eşzamanlı kullanımından kaçınmak gerekmediğini ortaya koyması bakımından önemlidir. Bu konuda daha ileri ve geniş kapsamlı çalışmalara ihtiyaç bulunmaktadır.

Anahtar kelimeler: pazopanib, proton pompa inhibitörü, eşzamanlı, sağkalım, sarkom.

\section{INTRODUCTION}

Soft tissue sarcomas (STS) are a heterogeneous group of cancers which are varying in clinical behavior, pathogenesis, and genetic features ${ }^{1,2}$. Response to treatment is insufficient in most patients with metastatic STS, and the median overall survival (OS) is approximately one year despite the anthracycline-based chemotherapy ${ }^{3,4}$. Therefore, new approaches and therapeutic agents are needed for these patients.

Pazopanib is a novel multi-target tyrosine kinase inhibitor (TKI) that was approved for the treatment of patients with advanced STS (aSTS) as well as in patients with metastatic renal cell cancer (mRCC) $)^{5,6}$. Pazopanib is administered orally, and because of its poor solubility at $\mathrm{pH}$ 1.1 and almost insoluble above $\mathrm{pH} 4$, absorption of pazopanib requires a physiological gastric acidity ${ }^{7}$. Moreover, a threshold for plasma pazopanib concentration which must be achieved for optimal efficacy of pazopanib was identified both in patients with mRCC and with aSTS, and it has been suggested that maintenance of plasma pazopanib concentrations above this threshold is associated with increased progression-free survival (PFS) and tumor shrinkage ${ }^{8,9}$. However, an elevated gastric $\mathrm{pH}$ because of the 
concomitant use of pazopanib and acidreducing drugs (ARDs) such as proton pump inhibitors (PPI) decreases the average maximum pazopanib plasma concentration and may adversely affect the bioavailability of pazopanib ${ }^{10}$. Although most cancer patients often receive ARDs to relieve dyspeptic symptoms that are evident due to intensive treatment processes, it has been recommended that alternative agents that do not alter gastric $\mathrm{pH}$ at the time of receiving pazopanib should be considered $^{11,12}$. On the contrary, it has been demonstrated that concomitant use of ARDs and pazopanib was not associated with decreased PFS or OS in patients with MRCC; therefore clinicians are advised to consider allowing patients to remain on concomitant ARDs and pazopanib ${ }^{13}$. However, there is a lack of knowledge of the concomitant use of ARDs and pazopanib in patients with aSTS.

Because of the limited and confusing literature, we designed this retrospective study to evaluate the real-life clinical outcomes of coadministrating PPI and pazopanib in patients with aSTS.

\section{METHODS}

This retrospective and cross-sectional study was conducted in two cancer centers. The study was performed according to the Declaration of Helsinki and approved by the Local Ethics Committee of the university (Local Ethics Committee approval number: 2019/1801). Since this was a retrospective file screening study, informed consent was not required.

Age $\geq 18$, having pathologically proven STS, receiving pazopanib at least one day for an unresectable local recurrence or a metastatic lesion, and availability of information about the use of PPI during pazopanib treatment were the inclusion criteria. Patients with adipocytic sarcoma and patients with no reliable information about PPI use were excluded.

In this study, we identified 79 patients with aSTS who were treated with pazopanib between January 1, 2013, and April 15, 2019. We determined the information about PPI use of patients via hospital files and electronic prescription system. However, we could not obtain reliable data on PPI use in 33 patients. Therefore, we excluded them from the study, and then we examined the remaining 46 patients whose information about PPI use were utterly available. These patients were categorized into two groups regarding concomitant use of PPI and pazopanib during the treatment: a) never used PPI, and b) used PPI. Also, we divided the PPI users as occasionally users and frequently/ regularly users.

The response evaluation of the patients was done according to the Response Evaluation Criteria in Solid Tumors (RECIST) version 1.1. Patients who achieved a complete response (CR), partial response (PR), and stable disease (SD) in accordance with RECIST were defined as responders. In contrast, patients with progressive disease (PD) were identified as non-responders. The overall response rate (ORR) was defined as the responders, including only CR or PR.

Statistical analysis was performed by using SPSS version 22.0 (SPSS Inc., Chicago, IL, USA). A pvalue $<0.05$ was required for statistical significance. The overall response rate (ORR) was defined as the responders, including the only complete or partial response. PFS was calculated as the time from the beginning of pazopanib to the date of first disease progression or death from any cause in the period of treatment. OS was determined by measuring the time from the beginning of pazopanib to death or the last follow-up examination. Follow-up was defined as the time from the diagnosis to death or the last follow-up examination. All patients underwent PFS, OS, and follow-up analysis. Primary statistical analysis has included descriptive statistics of the patients. Descriptive statistics were calculated as proportions and medians. The Kaplan-Meier method was used for the survival analysis. LogRank analysis was performed to compare the different subgroups. Univariate and multivariate 
logistic regression analyses were used to identify independent variables.

\section{RESULTS}

\section{Patient Characteristics}

A total of 46 eligible patients were assessed in this study. The median age was 48.6 years (range; 19-81 years). All patients started to receive pazopanib at the daily dose of $800 \mathrm{mg}$. The dose reduction was required in 4 patients (8.7\%). The average dose intensity of pazopanib was $769.6 \mathrm{mg}$ (400-800). Thirty-one patients (67.4\%) used concomitant PPI and pazopanib in the duration of treatment, 17 of them frequently used PPI, and the others occasionally. Fifteen patients (32.6\%) never used concomitant PPI and pazopanib. The numbers of responder and non-responder patients were 20 (43.5\%) and 26 (56.5\%), respectively. The stable disease was detected in most of the responder patients. The ORR was $21.8 \%$. The demographic and clinical parameters of patients are shown in Table-1.

\section{Survival Outcomes}

The median PFS, OS, and follow-up were 3.97 months (95\% CI: 2.99-4.96), 13.63 months (95\% CI: 5.83-21.44), and 32.72 months (95\% CI: 21.73-43.72), respectively. Moreover, the median PFS was 2.76 months (95\% CI: 2.39$3.13)$, and the median OS was 7.39 months (95\% CI: 2.69-12.09) for patients who never used concomitant PPI and pazopanib. Also, the median PFS was 5.22 months (95\% CI: 3.137.31 ), and the median OS was 14.52 months (95\% CI: 12.82-16.22) for patients who used concomitant PPI and pazopanib. Figure-1 shows the survival analyses for PFS and OS.

In univariate analysis; using concomitant PPI $(p=0.049)$ and primarily uterine located tumors $(\mathrm{p}=0.038)$ were significant parameters for PFS. No parameter was significant for OS. Figure-2 shows the Kaplan-Meier curves of univariate analyses for PFS.

Table I. The demographic and clinical parameters of patients.

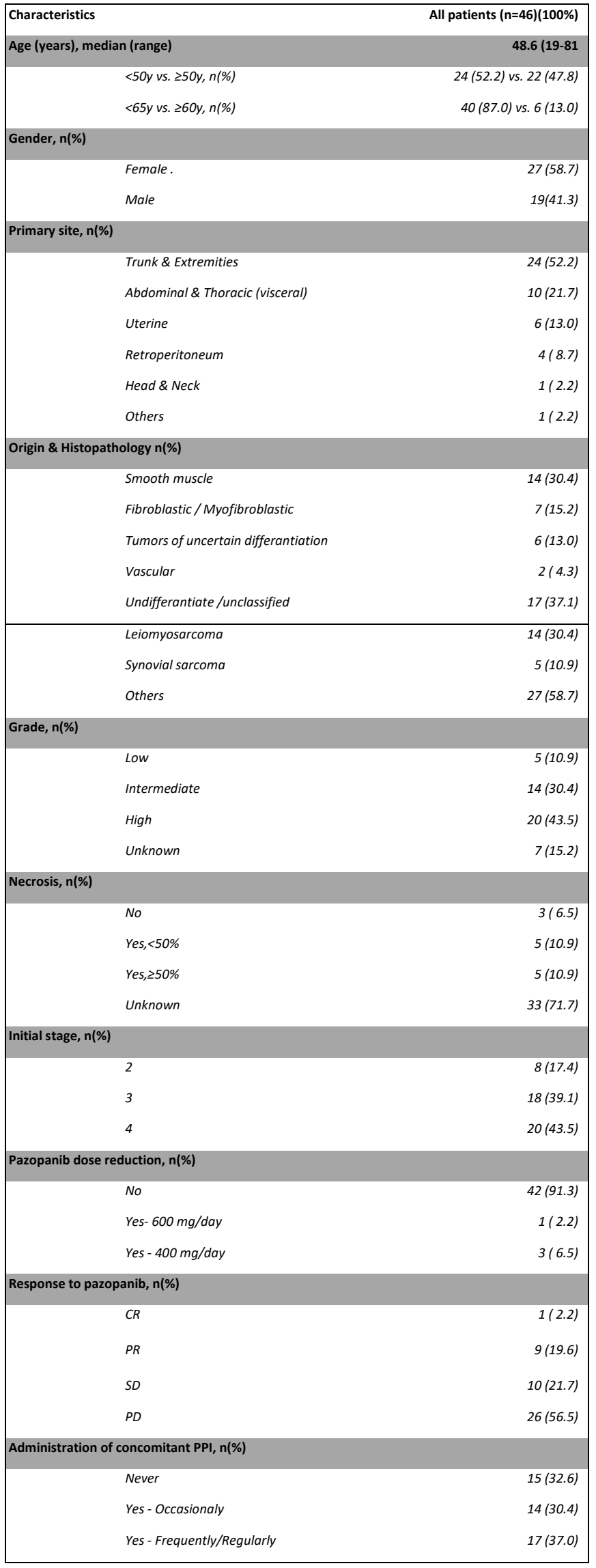

n; Number of patients, ECOG-PS; Eastern Cooperative Oncology Group-Performance Status, CR; Complete response, PR; Partial response, SD; Stable disease, PD; Progressive disease 

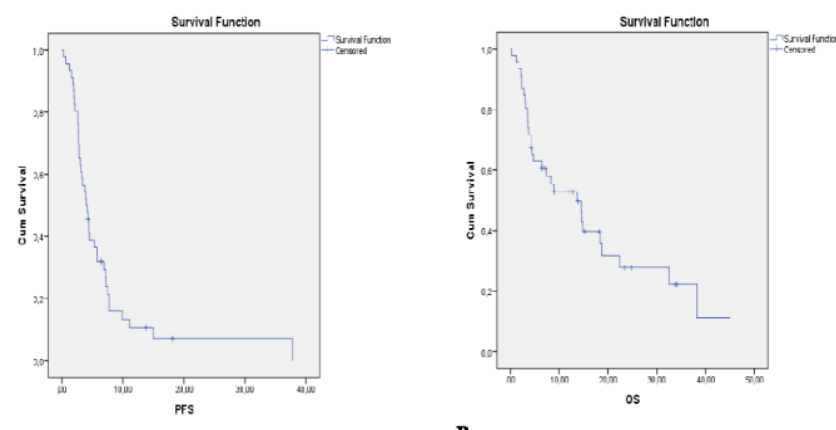

B

Figure 1. The survival analyses for progression-free survival and overall survival.

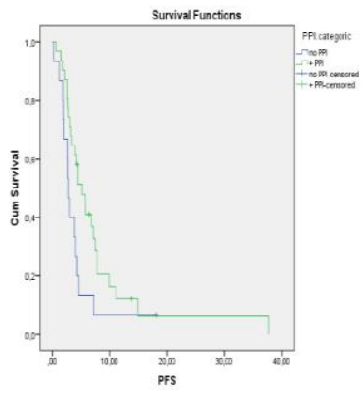

A

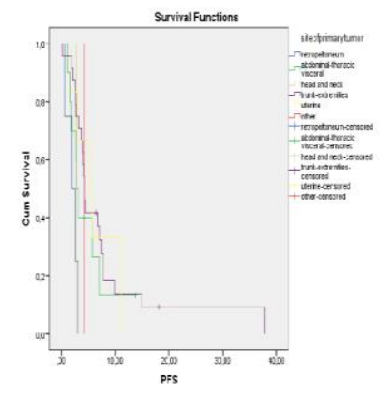

B

Figure 2. Kaplan-Meier curves of univariate analyses for progression-free survival.

Therefore, multivariate logistic regression analysis was performed to identify factors associated with longer PFS. As a result, using concomitant PPI (Wald=6.02; $\mathrm{p}=0.014$ ) and primarily uterine located tumors (Wald $=5.69$; $\mathrm{p}=0.017$ ) retained their association with longer PFS.

Grouping the using concomitant PPI as occasionally and frequently did not have statistically significant effects on PFS and OS.

\section{DISCUSSION}

This study is the first study investigating the clinical outcomes of our cohort with aSTS who used concomitant PPI and pazopanib. The primary purpose of this study was to assess whether the use of concomitant PPI and pazopanib have negative effects on survival outcomes, and surprisingly, we found that using concomitant PPI and pazopanib for aSTS is associated with prolonged PFS. Furthermore, we showed that primarily uterine located tumors are also associated with prolonged PFS.
This study is critical because it includes real-life data of patients beyond the data of highly selected patients of clinical trials, and is critical because of the first time revealing noninferiority/superiority on PFS of using concomitant PPI and pazopanib in patients with aSTS.

In daily practice, when treating many cancer patients, clinicians have to use ARDs such as PPI due to various dyspeptic complaints. Furthermore, like many drugs used to treat cancer, pazopanib itself causes dyspepsia in patients $^{14}$. Therefore, many of the patients treated with pazopanib need to use concomitant ARDs. But, it has been suggested that many TKIs such as pazopanib reveals $\mathrm{pH}$-dependent bioavailability, and their absorption may be decreased by the use of concomitant ARDs that elevate gastric $\mathrm{pH}^{10}$. However, the current literature is not clear about the use of concomitant ARDs and TKIs, and there are confusing publications and recommendations.

Many studies are indicating that treatment failure will occur as a result of drug-drug interaction, and recommend to avoid using concurrent PPI and TKIs ${ }^{7-10,15}$. On the other hand, although a study with nilotinib which is another TKI showed that the absorption of the drug decreased as a result of using concurrent PPI, it was stated that the decrease was at a modest level and that nilotinib may be used concurrently with PPI ${ }^{16}$. Moreover, many studies demonstrated that using concomitant PPI and erlotinib in patients with lung cancer has not resulted in treatment failure, and that co-administration of PPI and erlotinib may be allowed in 17,18 . Very soon, it has been demonstrated that using concomitant ARDs and pazopanib was not shown to be associated with decreased PFS or OS in patients with mRCC ${ }^{13}$. To the best of our knowledge, our study is the first that demonstrates the treatment success rather than the treatment failure of using concomitant PPI and pazopanib in patients with aSTS. The results of our study confirm the validity of the current practice of clinicians to allow the use of concomitant PPI for the symptomatic relief of dyspeptic symptoms, considering that the 
primary goal of pazopanib treatment in patients with aSTS is primarily palliative. Besides, the results of this study rule out the contrary opinion that treatment failure may occur as a result of the concomitant use of PPI and TKIs, which has become a subject of concern for the design of clinical trials and patients selection.

Also, we found that the median PFS and OS were 3.97 months and 13.63 months, respectively. The median PFS and OS of our cohort are consistent with the literature ${ }^{5,19}$.

Another result of this study was that primarily uterine located tumors were associated with prolonged PFS in patients with aSTS using pazopanib. When we searched the literature on this issue, we could not obtain precise data on the prognostic value of uterine localization of the tumor in patients with STS. In a retrospective of patients with STS, it was reported that there was no relationship between localization of the tumor and survival $^{20}$. However, leiomyosarcoma is the most common histological subtype of STS located at the uterus, and it has been reported that patients receiving pazopanib for leiomyosarcoma have better results than the patients with other histological subtypes in terms of PFS and $\mathrm{OS}^{19}$. Although the number of patients in our study is small, it may be helpful for clinicians to keep in mind that using pazopanib in uterine located STS patients results in better PFS.

The limitations of this study are that the low number of patients, the lack of randomization, the lack of time of administration of each drug during the day (because acid secretion has circadian rhythm), and the insufficiency of data on whole ARDs. It is worth noting that, indeed we wanted to examine the concomitant use of all ARDs and pazopanib, but we had to evaluate only the concomitant use of PPI and pazopanib because we could not obtain sufficient and reliable data on the other ARDs. Besides, we could not subdivide PPI into esomeprazole, pantoprazole, lansoprazole, and omeprazole due to heterogeneous PPI preferences of patients or physicians, and because of the small number of our cohort. Further studies with a large number of patients and randomized design may be mandatory to confirm our results.

\section{Acknowledgment}

This research did not receive any specific grant from funding agencies in the public, commercial, or not-for-profit sectors. All authors contributed significantly to the study from beginning to the end by making important additives to conception, design, collection of data, or analysis and interpretation of data, drafting the manuscript or revising it critically.

Ethics Committee Approval: The study was performed according to the Declaration of Helsinki and approved by the Local Ethics Committee of the university (Local Ethics Committee approval number: 2019/1801).

Declaration of Conflicting Interests: The authors declare that they have no conflict of interest.

Financial Disclosure: No financial support was received.

\section{REFERENCES}

1. American Cancer Society. Cancer Facts \& Figures 2017. Atlanta: American Cancer Society. 2017.

2. Blay J-Y, van Glabbeke M, Verweij J, et al. Advanced soft-tissue sarcoma: a disease that is potentially curable for a subset of patients treated with chemotherapy. Eur J Cancer. 2003; 39: 64-69.

3. Kasper B, Hohenberger P. Pazopanib: a promising new agent in the treatment of soft tissue sarcomas. Futur Oncol. 2011; 7: 1373-83.

4. Kasper B, Sleijfer S, Litière S, et al. Long-term responders and survivors on pazopanib for advanced soft tissue sarcomas: Subanalysis of two European Organisation for Research and Treatment of Cancer (EORTC) clinical trials 62043 and 62072. Ann Oncol. 2014; 25: 719-24.

5. Van Der Graaf WT, Blay JY, Chawla SP, et al. Pazopanib for metastatic soft-tissue sarcoma (PALETTE): A randomised, double-blind, 
placebo-controlled phase 3 trial. Lancet. 2012; 379: 1879-86.

6. Hutson TE, Davis ID, Machiels JPH, et al. Efficacy and safety of pazopanib in patients with metastatic renal cell carcinoma. J Clin Oncol. 2010; 28: 475-80.

7. Budha NR, Frymoyer A, Smelick GS, et al. Drug absorption interactions between oral targeted anticancer agents and PPIs: Is pH-dependent solubility the achilles heel of targeted therapy. Clin Pharmacol Ther. 2012; 92: 203-13.

8. Suttle AB, Ball HA, Molimard $M$, et al. Relationships between pazopanib exposure and clinical safety and efficacy in patients with advanced renal cell carcinoma. Br J Cancer. 2014; 111: 1909-16.

9. Verheijen RB, Swart LE, Beijnen JH, Schellens JHM, Huitema ADR, Steeghs N. Exposuresurvival analyses of pazopanib in renal cell carcinoma and soft tissue sarcoma patients: opportunities for dose optimization. Cancer Chemother Pharmacol. 2017; 80: 1171-78.

10. Tan AR, Gibbon DG, Stein MN, et al. Effects of ketoconazole and esomeprazole on the pharmacokinetics of pazopanib in patients with solid tumors. Cancer Chemother Pharmacol. 2013; 71: 1635-43.

11. Smelick GS, Heffron TP, Chu L, et al. Prevalence of acid-reducing agents (ARA) in cancer populations and ARA drug-drug interaction potential for molecular targeted agents in clinical development. Mol Pharm. 2013; 10: 4055-62.

12. Mir $\mathrm{O}$, Touati $\mathrm{N}$, Lia $\mathrm{M}$, et al. Impact of concomitant administration of gastric acidsuppressive agents and pazopanib on outcomes in soft-tissue sarcoma patients treated within the EORTC 62043/62072 trials. Clin Cancer Res. 2019; 25: 1479-85.
13. McAlister RK, Aston J, Pollack M, Du L, Koyama T, Chism DD. Effect of Concomitant pHElevating Medications with Pazopanib on Progression-Free Survival and Overall Survival in Patients with Metastatic Renal Cell Carcinoma. Oncologist. 2018; 23: 686-92.

14. Votrient ${ }^{\circledR}$ [packageinsert]. East Hanover, NJ: Novartis Pharmaceuticals Corporation. 2017.

15. van Leeuwen RWF, Peric R, Hussaarts KGAM, et al. Influence of the Acidic Beverage Cola on the Absorption of Erlotinib in Patients With Non-Small-Cell Lung Cancer. J Clin Oncol. 2016; 34: 1309-14.

16. Yin OQP, Gallagher N, Fischer D, et al. Effect of the Proton Pump Inhibitor Esomeprazole on the Oral Absorption and Pharmacokinetics of Nilotinib. J Clin Pharmacol. 2010; 50: 960-67.

17. Ter Heine R, Fanggiday JC, Lankheet NAG, et al. Erlotinib and pantoprazole: a relevant interaction or not? Br J Clin Pharmacol. 2010; 70: 908-11.

18. Hilton JF, Tu D, Seymour L, Shepherd FA, Bradbury PA. An evaluation of the possible interaction of gastric acid suppressing medication and the EGFR tyrosine kinase inhibitor erlotinib. Lung Cancer. 2013; 82: 13642.

19. Nakamura T, Matsumine A, Kawai A, et al. The clinical outcome of pazopanib treatment in Japanese patients with relapsed soft tissue sarcoma: A Japanese Musculoskeletal Oncology Group (JMOG) study. Cancer. 2016; 122: 140816.

20. Duman BB, Gunaldi M, Ercolak V, et al. Retrospective analysis of 498 primary soft tissue sarcomas in a single Turkish centre. Asian Pac J Cancer Prev. 2012; 13: 4125-28. 